\title{
Hypomethylation of Tumor Suppressor Genes in Odontogenic Myxoma
}

\author{
Paula Rocha MOREIRA ${ }^{1}$ \\ Fabiano Pereira CARDOSO ${ }^{2}$ \\ João Artur Ricieri BRITO² \\ Aline Carvalho BATISTA ${ }^{3}$ \\ Carolina Cavaliéri GOMES ${ }^{4}$ \\ Ricardo Santiago GOMEZ ${ }^{2}$
}

\author{
${ }^{1}$ Laboratory of Cell-Cell Interactions, Department of Morphology, Institute of Biological Sciences, \\ UFMG - Federal University of Minas Gerais, Belo Horizonte, MG, Brazil \\ ${ }^{2}$ Laboratory of Molecular Biology, Department of Oral Surgery and Pathology, Dental School, \\ UFMG - Federal University of Minas Gerais, Belo Horizonte, MG, Brazil \\ ${ }^{3}$ Department of Stomatology, Dental School, UFG - Federal University of Goiás, Goiânia, GO, Brazil \\ ${ }^{4}$ Department of Pathology, UFMG - Federal University of Minas Gerais, Belo Horizonte, MG, Brazil
}

\begin{abstract}
Odontogenic myxoma (OM) is an ectomesenchymal benign odontogenic tumor characterized by spindle or stellate-shaped cells embedded in an abundant myxoid or mucoid extracellular matrix. DNA methylation is characterized by the addition of methyl groups in cytosines within $\mathrm{CpG}$ islands in the promoter gene. DNA methylation can decrease the expression of tumor suppressor genes and contribute to the development of neoplastic lesions. The aim of study was to evaluate the methylation pattern of the tumor suppressor genes P16 (CDKN2A), P21 (CDKN1A), P27 (CDKN1B), P53 (TP53) and RB1 in OM and dental pulp. Methylation was evaluated using methylation-specific polymerase chain reaction (PCR). The transcription was studied in some cases by using reverse transcription quantitative PCR. A higher frequency of unmethylated P27, P53, and $R B 1$ samples was observed in the OM when compared with the dental pulp. OM expressed mRNA of all the genes evaluated. Considering all the samples together, the expression of Rb was higher in the unmethylated samples compared with the partially methylated samples. This investigation revealed hypomethylation of the genes $P 27, P 53$, and RB1 in OM. In addition, methylation of tumor suppressor genes was found to be an usual event in normal dental pulp.
\end{abstract}

Key Words: methylation, tumor suppressor genes, odontogenic myxoma, dental pulp.

\section{INTRODUCTION}

Odontogenicmyxoma $(\mathrm{OM})$ isanectomesenchymal benign odontogenic tumor characterized by stellate and spindle-shaped cells embedded in an abundant myxoid or mucoid extracellular matrix (1). This locally aggressive neoplasm is the second most common odontogenic neoplasm (after ameloblastoma), with an incidence of approximately 0.07 new cases per million people per year (2). Despite its benign nature, $\mathrm{OM}$ has a high rate of local recurrence after curettage alone (3). Although mutations of the regulatory subunit 1 A of protein kinase. A have been described in OM (4), little is known about its molecular pathogenesis.

DNA methylation is an efficient epigenetic mechanism of transcriptional repression that occurs in cytosines within $\mathrm{CpG}$ dinucleotides. The presence or absence of methyl groups in cytosines promotes the remodeling of chromatin, making it less or more accessible to transcription (5). Epigenetic alterations related to the regulation of genes involved in the cell cycle control have been described in different benign and malignant neoplasms (6-8). Recently, distinct methylation profiles in tumor suppressor genes have been reported in epithelial odontogenic tumors (9). The present study is the first attempt to investigate the methylation profile of OM. Methylation pattern of the following tumor suppressor genes was investigated in OM and dental pulps: $P 16$ (CDKN2A), P21 (CDKN1A), $P 27$ (CDKN1B), P53 (TP53) and RB1. In order to

Correspondence: Profa. Dra. Paula Rocha Moreira, Laboratório de Biologia Molecular, Faculdade de Odontologia, UFMG, Avenida Antônio Carlos, 6627, Pampulha, 31270-901 Belo Horizonte, MG, Brasil. Tel: +55-31-3409-2477. Fax:+55-31-3409-2430. e-mail address: paularocha@ufmg.br 
validate the importance of methylation profile in the regulation of gene expression, the transcription of tumor suppressor genes was also studied in some cases.

\section{MATERIAL AND METHODS}

\section{Samples}

Twenty-four samples were examined in this study, which included 9 samples of OM and 15 samples of dental pulp tissue. The OM group was composed of samples of 6 female and 3 male subjects (age ranging from 13 to 34 years), and the dental pulp group was composed of 12 female and 3 male subjects (age ranging from 16 to 29 years).

Fresh samples and paraffin-embedded tissues of OM were collected during incisional biopsy, enucleation, or resection of the lesion. Pulp tissue samples were obtained from the third molar impacted teeth extracted from healthy volunteers. The fresh samples were immediately included in Tissue-Tek (Sakura Finetek, Torrance, CA, USA) and stored at $-80^{\circ} \mathrm{C}$. Paraffinembedded tissues were previously fixed in $10 \%$ formalin. For RNA extraction, a piece of the tissue was stored in RNAholder (BioAgency Biotecnologia, São Paulo, SP, Brazil) at $-80^{\circ} \mathrm{C}$. This study was approved by UFMG's Ethics Committee (Protocol \#COEP 266/11).

\section{DNA Extraction}

Genomic DNA from tissue sections of 24 samples was extracted with the QIAamp DNA Mini kit (Qiagen, Hilden, Germany), as per the manufacturer's protocol.

\section{Bisulfite Modification}

The methylation pattern of tissues was assessed using DNA modification by bisulfite treatment, similar to that reported by Goldenberg et al. (10). With the bisulfite treatment, unmethylated cytosines of DNA are converted to uracil while methylated cytosines remain unmodified. Bisulfite conversion was carried out with $1 \mu \mathrm{g}$ of DNA, which was denatured by incubation with $2 \mu \mathrm{L}$ of $\mathrm{NaOH}$ $(3 \mathrm{M})$ for $20 \mathrm{~min}$ at $50^{\circ} \mathrm{C}$. Then, the amples were treated with sodium bisulfite $(2.5 \mathrm{M})$ and hydroquinone $(1 \mathrm{M})$ for $3 \mathrm{~h}$ at $70^{\circ} \mathrm{C}$. Modified DNA samples were purified with Wizard DNA purification resin, as per manufacturer's instructions, (Promega, Madison, WI, USA) and eluted in distilled $\mathrm{H}_{2} \mathrm{O}$. $\mathrm{NaOH}(3 \mathrm{M})$ was added to complete the modification, followed by ethanol precipitation. Pellets were resuspended, and 200 ng of DNA were used for the polymerase chain reaction (PCR) assay.

\section{Methylation-Specific PCR (MSP-PCR)}

The MSP-PCR distinguishes the presence of methylation in a given gene by using specific primers for methylated or unmethylated DNA sequences. Primer sequences and amplification conditions used to evaluate P16, P21, P27, P53, and RB1 genes were previously reported (8,11-13). The reactions were performed in a thermocycler (Eppendorf AG, Hamburg, Germany), and the PCR products were visualized in silver-stained $6.5 \%$ polyacrylamide gel.

Genomic DNA treated with SssI methylase (New England Biolabs, Ipswich, MA, USA) was used as positive control in the specific reactions for the methylated DNA. DNA from peripheral blood mononuclear cells was used as positive control for unmethylated genes.

Positive amplification only for methylated primers was interpreted as total methylation. Positive amplification for both methylated and unmethylated primers was considered as partial methylation, according to the literature (14).

\section{RNA Extraction and Reverse Transcription Quantitative} Real-Time PCR (RT-qPCR)

Total RNA was extracted from 10 samples collected in RNAholder (BioAgency Biotecnologia), which included two OM samples and eight dental pulp samples. RNA was extracted using Trizol reagent and then was treated with RNAse-free DNAase I (Invitrogen Life Technologies, Carlsbad, CA, USA), according to the manufacturer's protocol. cDNA was synthesized from 1 $\mu \mathrm{g}$ of total RNA by using superscript first-strand synthesis system (Invitrogen Life Technologies). RT-qPCR was performed using TaqMan fluorescence quantification system in a Step-One real-time PCR 48-well plate (Applied Biosystems, Warrington, UK). The reactions were performed with the TaqMan ${ }^{\circledR}$ Gene expression assays (Applied Biosystems) for P16 (Hs99999189), P21 (Hs99999142), P27 (Hs00153277), TP53 (Hs01034249) and RB1 (Hs00153108). As endogenous control, we used the kit TaqMan ${ }^{\circledR}$ ACTB (beta-actin, RefSeq NM_001101.2, Applied Biosystems).

Relative gene expression was calculated using 
the $2^{-\Delta \Delta C t}$ method (Applied Biosystems User Bulletin No. 2) as previously described (15), and the expression data were normalized with endogenous beta-actin. Data were presented as the relative quantity of target gene normalized to endogenous beta-actin and relative to a calibrator sample. As calibrator, we used a pool of blood samples of healthy individuals.

\section{Statistical Analysis}

Statistical analysis of data was performed using the Mann-Whitney test and Fisher's exact test from BioEstat 4.0 software (Mamirauá Maintainable Development Institute, Belém, PA, Brazil). A p value of $<0.05$ was considered significant.

\section{RESULTS}

\section{MSP-PCR Results}

The number and percentage of samples with total/partial methylated and unmethylated sequences of $\mathrm{OM}$ and dental pulp in each gene studied are shown in Figure 1. A higher percentage of methylated (partially or totally) samples was observed in the dental pulp group. Regarding both groups, a low frequency of total methylation (positive only for the methylated sequence of the gene) was observed for all the genes. In the dental pulp group, the majority of samples showed partial methylation for all genes (data not shown). In the OM group, the majority of samples were unmethylated (showed amplification only with the unmethylated primers) for P21 (77.8\%), P27 (55.6\%), P53 (77.8\%), and RB1 (88.9\%). A higher frequency of unmethylated samples was observed in the OM group when compared with the dental pulp group for P27, P53, and RB1 genes (Fig. 1). No statistically significant difference ( $\mathrm{p}>0.05)$ was observed considering P16 and P21 genes.

\section{RT-qPCR Results}

In order to validate the importance of the methylation profile in the regulation of gene expression, the transcription of tumor suppressor genes was performed in two and eight samples of OM and dental pulp, respectively (Tables 1-5). Undetectable level of $\mathrm{Rb}$ mRNA was observed in all the samples with partial methylation, while the unmethylated samples showed

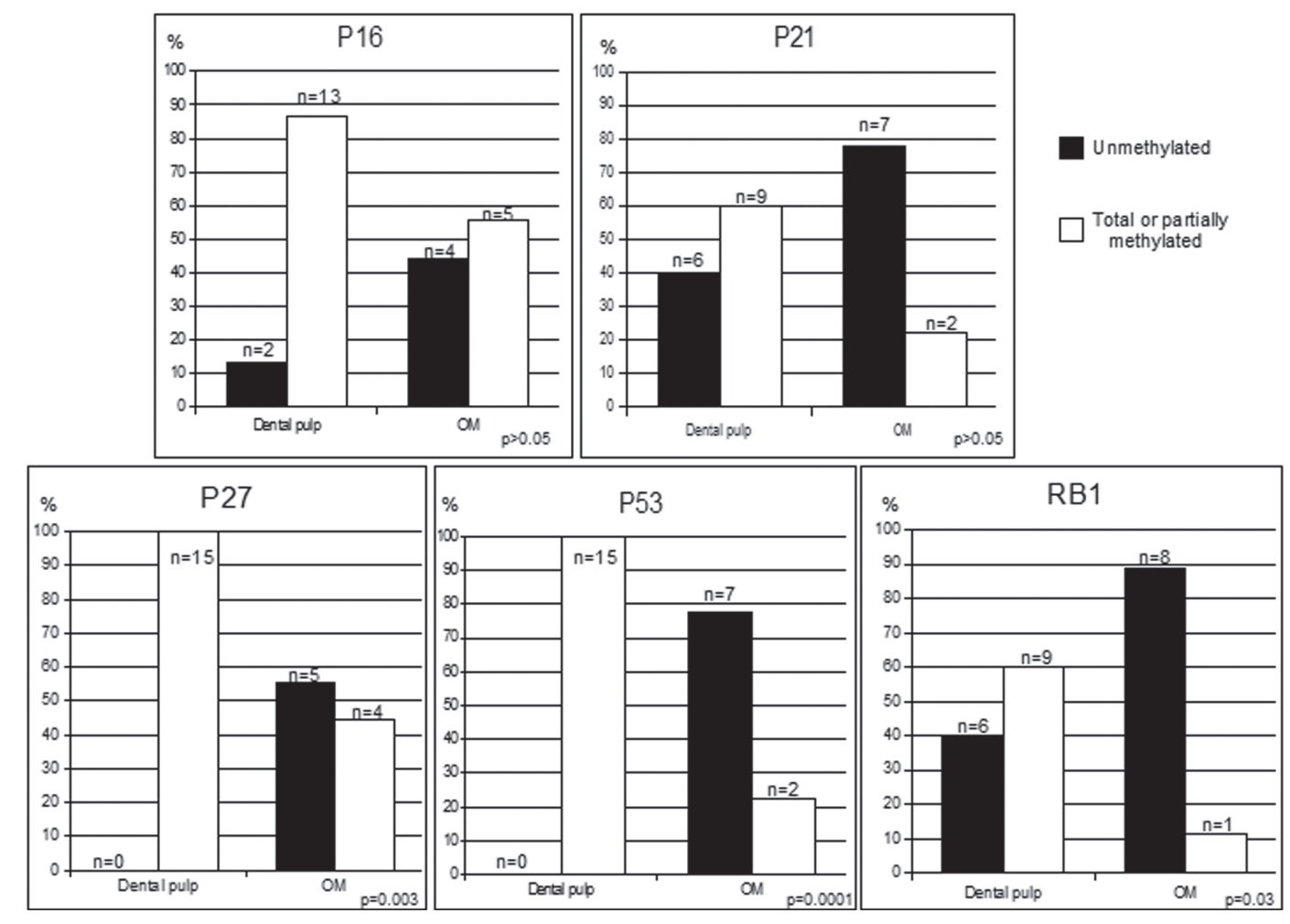

Figure 1. Number and percentage of samples with total/partial methylated and unmethylated sequences of OM (odontogenic myxoma) and dental pulp in each gene studied by MSP-PCR. 
transcription of the gene (relative quantity ranging from 5.06 to 11.22) $(\mathrm{p}=0.0167)$. Expression of the P21 gene did not show statistically significant difference between unmethylated and partially methylated samples $(\mathrm{p}=0.21)$. As only one unmethylated sample was observed for P16, P27 and P53 genes, no statistical analysis was performed between gene expression in unmethylated versus partially methylated samples for these genes.

Except for case 1 of OM, which showed undetectable levels of p16, both OM samples expressed

Table 1. Results of MSP-PCR and RT-qPCR for P16.

\begin{tabular}{|c|c|c|c|}
\hline \multirow{2}{*}{ Samples } & \multicolumn{2}{|c|}{ MSP-PCR } & \multirow{2}{*}{$\frac{\text { RT-qPCR }}{\text { RQ }}$} \\
\hline & Unmethylated & Methylated & \\
\hline OM1 & + & + & Undetectable \\
\hline $\mathrm{OM} 2$ & + & - & 4.87 \\
\hline DP1 & + & + & Undetectable \\
\hline DP2 & + & + & 28.38 \\
\hline DP3 & + & + & Undetectable \\
\hline DP4 & + & + & Undetectable \\
\hline DP5 & + & + & 650.12 \\
\hline DP6 & + & + & 1533.21 \\
\hline DP7 & + & + & Undetectable \\
\hline DP8 & + & + & Undetectable \\
\hline
\end{tabular}

OM: odontogenic myxoma; DP: dental pulp; RQ: relative quantity.

Table 3. Results of MSP-PCR and RT-qPCR for P27.

\begin{tabular}{lcccc}
\hline \multirow{2}{*}{ Samples } & \multicolumn{2}{c}{ MSP-PCR } & & RT-qPCR \\
\cline { 2 - 3 } \cline { 5 - 5 } & Unmethylated & Methylated & & RQ \\
\hline OM1 & + & - & & 7.21 \\
OM2 & + & + & 4.1 \\
DP1 & + & + & Undetectable \\
DP2 & + & + & 1.38 \\
DP3 & + & + & & Undetectable \\
DP4 & + & + & & Undetectable \\
DP5 & + & + & & Undetectable \\
DP6 & + & + & & 386.68 \\
DP7 & + & + & & 46.28 \\
DP8 & + & + & & 104.09 \\
\hline
\end{tabular}

OM: odontogenic myxoma; DP: dental pulp; RQ: relative quantity. all the genes. Because of the small number of fresh samples of $\mathrm{OM}(\mathrm{n}=2)$, no statistical analysis comparing with dental pulp was performed.

\section{DISCUSSION}

OMs are extensively described as case report

Table 2. Results of MSP-PCR and RT-qPCR for P21.

\begin{tabular}{lcccc}
\hline \multirow{2}{*}{ Samples } & \multicolumn{2}{c}{ MSP-PCR } & & RT-qPCR \\
\cline { 2 - 3 } \cline { 5 - 5 } & Unmethylated & Methylated & & RQ \\
\hline OM1 & + & + & & 46.5 \\
OM2 & + & - & & 11.64 \\
DP1 & + & - & Undetectable \\
DP2 & + & - & 6.41 \\
DP3 & + & + & \\
DP4 & + & + & & Undetectable \\
DP5 & + & + & & Undetectable \\
DP6 & + & + & & 62.98 \\
DP7 & + & + & & 24 \\
DP8 & + & + & & 42.54 \\
\hline
\end{tabular}

OM: odontogenic myxoma; DP: dental pulp; RQ: relative quantity. Considering all samples together, p21 expression in the cases with unmethylated sequences was not statistically different from those with partial or total methylation $(\mathrm{p}=0.21)$.

Table 4. Results of MSP-PCR and RT-qPCR for P53.

\begin{tabular}{lcccc}
\hline \multirow{2}{*}{ Samples } & \multicolumn{2}{c}{ MSP-PCR } & & RT-qPCR \\
\cline { 2 - 3 } \cline { 5 - 5 } & Unmethylated & Methylated & & RQ \\
\hline OM1 & + & - & 9.03 \\
OM2 & + & + & 1.79 \\
DP1 & + & + & Undetectable \\
DP2 & + & + & 2.38 \\
DP3 & + & + & Undetectable \\
DP4 & + & + & 21.77 \\
DP5 & + & + & 13.76 \\
DP6 & + & + & Undetectable \\
DP7 & + & + & 17.73 \\
DP8 & + & & + & 38.03 \\
\hline
\end{tabular}

OM: odontogenic myxoma; DP: dental pulp; RQ: relative quantity. 
studies, but the profile of molecular alterations has not yet been established. The molecular aspects associated with the invasive behavior of these lesions have not been explained.

Cell cycle control is mediated by the interaction of cyclins and cyclin-dependent kinases and can be deregulated by cyclin-dependent kinase inhibitors (CDKIs) (16). Epigenetic regulation of tumor suppressor genes, as CDKIs and important regulatory proteins, has been associated with the development of tumors $(7,17$, 18). The presence of methylation in CDKIs genes, as P16 (CDKN2A), P21 (CDKN1A), P27 (CDKN1B), and in regulatory protein genes, as $P 53$ (TP53) and RB1, may be implicated in transcriptional silencing and cell cycle control alterations.

In the present study, we searched for epigenetic alterations in OM. It was hypothesized that methylation of these genes would silence protein expression and would contribute to OM growth. However, methylation was more commonly detected in normal dental pulp cells than in OM. In addition, a higher frequency of unmethylated samples was observed in OM group when compared with dental pulp group for $P 27, P 53$, and $R B 1$ genes. It is interesting to note that albeit hypomethylation of transcription regulatory regions in cancer seems to be much less frequent than hypermethylation of $\mathrm{CpG}$ islands overlapping promoters (19), both hypermethylation and

Table 5. Results of MSP-PCR and RT-qPCR for RB1.

\begin{tabular}{|c|c|c|c|}
\hline \multirow{2}{*}{ Samples } & \multicolumn{2}{|c|}{ MSP-PCR } & \multirow{2}{*}{$\frac{\text { RT-qPCR }}{\text { RQ }}$} \\
\hline & Unmethylated & Methylated & \\
\hline OM1 & + & - & 5.06 \\
\hline OM2 & + & - & 11.22 \\
\hline DP1 & + & + & Undetectable \\
\hline DP2 & + & - & 5.9 \\
\hline DP3 & + & + & Undetectable \\
\hline DP4 & + & + & Undetectable \\
\hline DP5 & + & + & Undetectable \\
\hline DP6 & + & + & Undetectable \\
\hline DP7 & + & + & Undetectable \\
\hline DP8 & + & + & Undetectable \\
\hline
\end{tabular}

OM: odontogenic myxoma; DP: dental pulp; RQ: relative quantity. All samples taken together, increased RB1 expression in the cases with unmethylated sequences was observed compared with those with partial or total methylation $(\mathrm{p}=0.0167)$. hypomethylation are associated with DNA mutation. Although CpG sites have been shown to act as hotspots for mutations, hypomethylation of the genome can affect the intergenic and intronic regions of the DNA (20), particularly transposable elements, and it can cause chromosomal instability and increased mutation events (21). Another evidence that hypomethylation may be as dangerous as hypermethylation comes from the fact that global hypomethylation at genic $\mathrm{CpG}$ loci is an important and early mechanism driving multiple myeloma development (22). Further studies are necessary to depict the molecular consequences, if any, of the unmethylated sequences on the genome stability of OM. Investigation of the methylome profile of odontogenic tumors could be an additional target of molecular investigation in odontogenic tumors.

As the majority of tumor suppressor genes studied were not usually methylated in OM, it may be suggested that the expression of these genes would be a compensation for inappropriate control of the cell cycle already deregulated by the presence of different genetic alterations. Our research group described mutations of the PRKAR1A gene in OM samples (4). Rearrangements of the HMGA2 gene were also recently reported in OM (23). Furthermore, OM may present alterations in the apoptotic mechanisms that may contribute to the growth of these tumors (24). Whether these alterations have any association with the transcription of tumor suppressor genes in OM is a hypothesis that needs to be evaluated.

All genes evaluated were found to be expressed in OM. Because of the small number of $\mathrm{OM}$ fresh samples suitable for RNA extraction $(n=2)$, we have not compared RNA expression between OM and dental pulp. Considering all the samples together, the expression of $\mathrm{Rb}$ was higher in the unmethylated samples compared with the partially methylated samples. The $\mathrm{Rb}$ protein is a negative regulator of cell proliferation at $\mathrm{G} 1 / \mathrm{S}$ checkpoint complexing with transcriptional factors (25). The association between unmethylation and higher expression of $\mathrm{Rb}$ shows the importance of this epigenetic alteration in the regulation of the expression of this gene.

One limitation of the present study is the fact that abnormal DNA methylations in a neoplasm are snapshots of a specific time and place. The methylation analysis reveals the epigenetic status of the analyzed portion of the genome in the tumor when and where it was sampled, and it may not reflect the DNA methylation changes during tumor development and progression (19).

In conclusion, the present investigation showed 
hypomethylation of the genes $P 27, P 53$, and $R B 1$ in OM. Further studies are necessary to delineate the importance of these epigenetic alterations in OM pathogenesis. In addition, the present study demonstrated that methylation of the $P 16, P 21, P 27, P 53$, and $R B 1$ genes is an usual event in normal dental pulp cells.

\section{RESUMO}

O mixoma odontogênico (MO) é um tumor odontogênico benigno de origem mesenquimal caracterizado pela presença de células fusiformes ou estreladas dispostas em abundante matriz extracelular mucóide. A metilação do DNA é caracterizada pela adição de grupos metil em citosinas constituintes de ilhas $\mathrm{CpG}$ na região promotora do gene. A metilação pode diminuir a expressão de genes supressores de tumor e contribuir para o desenvolvimento de lesões neoplásicas. O objetivo deste trabalho foi avaliar o padrão de metilação nos genes $P 16$ (CDKN2A), P21 (CDKN1A), P27 (CDKN1B), P53 (TP53), RB1 nos MO e na polpa dental. A metilação foi avaliada pela reação em cadeia da polimerase específica para a metilação. A transcrição dos genes foi estudada em alguns casos pela reação da transcriptase reversa (PCR quantitativa). Uma maior frequência de amostras não metiladas para os genes $P 27, P 53$ e $R B 1$ foi observada nos MO quando comparados à polpa dental. Os MO expressaram RNAm de todos os genes avaliados. Considerando todas as amostras juntas, a expressão de $\mathrm{Rb}$ foi maior em amostras não metiladas comparadas as amostras parcialmente metiladas. Esta investigação mostrou a hipometilação dos genes $P 27, P 53$ e $R B 1$ nos MO. Adicionalmente, a metilação nos genes supressores de tumor é um evento frequente em polpa dental normal.

\section{ACKNOWLEDGEMENTS}

This study was supported by Fundação de Amparo à Pesquisa do Estado de Minas Gerais (FAPEMIG), Coordenação de Aperfeiçoamento de Pessoal de Nível Superior (CAPES), and Conselho Nacional de Desenvolvimento Científico e Tecnológico (CNPq), Brazil. Prof. RS Gomez is a research fellow of CNPq.

\section{REFERENCES}

1. Buchner A, Odell EW. Odontogenic myxoma/myxofibroma. In: Barnes L, Eveson JW, Reichart P, Sidransky D, eds. Pathology and genetics. Head and neck tumours. WHO Classification of tumours. Lyon: IARC Press; 2005; p. 316.

2. Simon EN, Merkx MA, Vuhahula E, Ngassapa D, Stoelinga PJ. Odontogenic myxoma: a clinicopathological study of 33 cases. Int J Oral Maxillofac Surg 2004;33:333-337.

3. Leiser Y, Abu-El-Naaj I, Peled M. Odontogenic myxoma: A case series and review of the surgical management. J Cranio-Maxillofac Surg 2009;37:206-209.

4. Perdigão PF, Stergiopoulos SG, De Marco L, Matyakhina L, Boikos SA, Gomez RS et al.. Molecular and immunohistochemical investigation of protein kinase a regulatory subunit Type 1A (PRKAR1A) in odontogenic myxomas. Genes Chromosomes Cancer 2005;44:204-211.

5. Narlikar GJ, Fan HY, Kingston RE. Cooperation between complexes that regulate chromatin structure and transcription. Cell 2002;108:475-487.

6. Nakahara Y, Shintani S, Mihara M, Hino S, Hamakawa H. Detection of $\mathrm{p} 16$ promoter methylation in the serum of oral cancer patients. Int J Oral Maxillofac Surg 2006;35:362-365.

7. Kishi M, Kakamura M, Nishimine M, Ikuta M, Kirita T, Konishi $\mathrm{N}$. Genetic and epigenetic alteration profiles for multiple genes in salivary gland carcinomas. Oral Oncol 2005;41:161-169.

8. Moreira PR, Guimarães MM, Guimarães A, Diniz M, Gomes C, Brito J et al.. Methylation of P16, P21, P27, RB1 and P53 genes in odontogenic keratocysts. J Oral Pathol Med 2009;38:99-103.

9. Moreira PR, Guimaraes MM, Gomes CC, Diniz M, Brito J, Castro W et al.. Methylation frequencies of cell-cycle associated genes in epithelial odontogenic tumors. Arch Oral Biol 2009;54:893-897.

10. Goldenberg D, Harden S, Masayesva BG, Ha P, Benoit N, Westra WH et al.. Intraoperative molecular margin analysis in head and neck cancer. Arch Otolaryngol Head Neck Surg 2004;130:39-44.

11. Herman JG, Graff JR, Myöhänen S, Nelkin BD, Baylin SB Methylation-specific PCR: a novel PCR assay for methylation status of CpG islands. Proc Natl Acad Sci USA 1996;93:98219826.

12. Brakensiek K, Langer F, Kreipe H, Lehmann U. Absence of p21(CIP1), p27(KIP1) and p57(KIP2) methylation in MDS and AML. Leuk Res 2005;29:1357-1360.

13. Park H-J, Yu E, Shim Y-H. DNA methyltransferase expression and DNA hypermethylation in human hepatocellular carcinoma Cancer Lett 2006;233:271-278.

14. Zhang C, Li K, Wei L, Li Z, Yu P, Teng L et al.. p300 expression repression by hypermethylation associated with tumour invasion and metastasis in oesophageal squamous cell carcinoma. J Clin Pathol 2007;60:1249-1253.

15. Livak KJ, Schimittgen T. Analysis of relative gene expression data using real-time quantitative PCR and the $2-\Delta \Delta \mathrm{Ct}$ method. Methods 2001;25:402-408.

16. Hunter T, Pines J. Cyclins and cancer II: cyclin D and CDK inhibitors come of age. Cell 1994;79:573-582.

17. Weber A, Wittekind C, Tannapfel A. Genetic and epigenetic alterations of 9 p21 gene products in benign and malignant tumors of head and neck. Pathol Res Pract 2003;199:391-397.

18. Li J, El-Naggar A, Mao L. Promoter methylation of p16 INK4a, RASSF1A and DAPK is frequent in salivary adenoid cystic carcinoma. Cancer 2005;104:771-776.

19. Ehrlich M. DNA hypomethylation in cancer cells. Epigenomics 2009;1:239-259.

20. Robertson KD, Jones PA. DNA methylation: past, present and future directions. Carcinogenesis 2000, 21:461-467.

21. Watanabe Y, Maekawa M. Methylation of DNA in cancer. Adv Clin Chem 2010;52:145-167.

22. Salhia B, Baker A, Ahmann G, Auclair D, Fonseca R, Carpten J. DNA methylation analysis determines the high frequency of genic hypomethylation and low frequency of hypermethylation events in plasma cell tumors. Cancer Res 2010;70:6934-6944.

23. Sato K, Terai K, Ozaki M, Ueda Y, Katsuda S. Odontogenic myxofibroma with HMGA2 overexpression and HMGA2 rearrangement. Pathol Int 2010;60:760-764.

24. Iezzi G, Piattelli A, Rubini C, Artese L, Fioroni M, Carinci F. MIB-1, Bcl-2 and p53 in odontogenic myxomas of the jaws. Acta Otorhinolaryngol Ital 2007;27:237-242.

25. Harbour JW, Dean DC. Rb function in cell-cycle regulation and apoptosis. Nat Cell Biol 2000, 2:E65-E67.

Received June 8, 2011 Accepted August 10, 2011 